\title{
28 Research Square \\ Examination of the Illness Representations among Children with T1DM in Relation to Mental Health Factors
}

\author{
Beáta Erika Nagy \\ Debreceni Egyetem \\ Brigitta Munkácsi \\ Debreceni Egyetem \\ Enikố Noémi Felszeghy \\ Debreceni Egyetem \\ Flóra Kenyhercz \\ Debreceni Egyetem \\ Gergő József Szôlloósi \\ Debreceni Egyetem \\ Karolina Eszter Kovács ( $\sim$ karolina92.kovacs@gmail.com ) \\ Debreceni Egyetem https://orcid.org/0000-0002-1186-7836
}

\section{Research Article}

Keywords: T1DM, illness representation, PRISM-D, depression, illness-circle

Posted Date: July 7th, 2021

DOI: https://doi.org/10.21203/rs.3.rs-494532/v1

License: @ (i) This work is licensed under a Creative Commons Attribution 4.0 International License. Read Full License 


\section{Abstract}

Background: This study aimed to investigate the association of the mental health and diabetes-specific variables with the illness representations in children with type 1 diabetes mellitus (T1DM).

Methods: A total of 115 children with T1DM were recruited through the outpatient clinic in Debrecen, Hungary. Our measures were The Pictorial Representation of Illness and Self Measure Drawing Test (PRISM-D), Child Depression Inventory (CDI), Cantril SelfAnchoring Striving Scale, and Self-Rated Health (SRH). Glycosylated haemoglobin (HbAlc) values were obtained from medical reports.

Results: We found significant mild correlations amongst the mental health factors. Those children who can be characterized with clinical depressive symptoms drew significantly fewer $(r=-0.253 ; p<0.05)$ circles with significantly less area $(r=-0.253 ; p<0.05)$ at the PRISM-D test. Furthermore, those children who did not draw any important relationships possessed significantly more depressive symptoms than those who drew at least one important person. Those children who were diagnosed at a younger age, reported significantly better health condition $(r=0.215 ; p=0.024)$, and displayed smaller distance $(r=-0.261 ; p=0.006)$ between the Self-circle and the Illness-circle.

Conclusions: The PRISM-D test provides a more complex picture of the subjective effect of the disease, and thus appears a promising additional tool to analyse the emotional and cognitive representations and the psychological burden of T1DM. Beside the medical treatment of the T1DM-children, the earliest screening and psychological interventions for mental health problems are of high priority.

\section{Introduction}

The most common comorbid psychiatric disorders in children with type 1 diabetes mellitus (T1DM) are depression, anxiety and behavioral disorders [1]. Patients with comorbid psychopathology are less capable of psychically adjusting to the new life situation resulting from T1DM [2], which may negatively affect glycemic control and adherence related to the treatment [3]. The improperly treated T1DM and the comorbid depression possibly lead to such negative medical consequences as a higher risk of hypoglycemic episodes [4], hospitalization for ketoacidosis [5] and lower health-related quality of life (HRQoL) [6]. According to Reynolds and Helgeson's [7] results, children with T1DM displayed fewer depressive symptoms than the control group. Since the results of casecontrol studies of depressive symptoms among T1DM-children are not congruent, a unitary conclusion cannot be drawn. The other most commonly measured dimension of mental health is satisfaction with life (SWL) which is a cognitive assessment of general quality of life-based on a person's own criteria [8]. As the number of studies into discovering the association between T1DM and satisfaction with life is rather slight in terms of its significance, we have made it one of the main purposes of our research. Beside SWL, we have examined the self-rated health (SRH) of children with T1DM, which is an informative global indicator of health condition and quality of life $[9 ; 10]$. Concerning studies conducted with adults, higher SRH scores predict better chances of survival [11; 12]; better functional health condition [13]; as well as lesser extent of dependence on medical service [14]. According to Huang et al. [15] results, the female gender, the higher parental socioeconomic status (SES), the earlier disease onset, the shorter duration of T1DM as well as the lower $\mathrm{HbA}_{1 \mathrm{c}}$-level [16] contributed to higher self-rated health in children, adolescents and young adults. The $\mathrm{SRH}$ associated with the severity of the disease, the mental and social functions [17; 18], and it is an important predictive factor of mortality and morbidity as well [19;20]. Self-rated health is one of the most significant global indicators of well-being and quality of life not only among adults as well as children, as it predicts to a higher accuracy the subsequent health condition and quality of life [21].

The examination of illness representations - the personal meaning of the disease [22] - can enrich with numerous important aspects the psychotherapy with children suffering from chronic disease. These representations determine what kind of implicit beliefs the patient develops about the disease and what kind of coping strategies the patient chooses [23].

On the basis of the results of international studies, the aim of our research was to examine the mental health of children with T1DM, with special consideration for satisfaction with life, self-rated health, frequency and severity of depressive symptoms as well as for the exploration of the association between these factors and the illness representations. 


\section{Method}

\section{Ethical concerns}

Our research was approved by the Regional Institutional Research Ethics Committee, Clinical Center, University of Debrecen (ID: 4528A-2016) following the ethical principles of the WMA Declaration of Helsinki. Written informed consent was obtained from all participants.

\section{Sample}

Our sample consisted of 115 T1DM children and adolescents. 60 girls $(52.17 \%), 55$ boys (47.83\%) participated, and their mean age was 14.13 years (min.: 8 yrs; max.: $18 \mathrm{yrs}$; $S D=2.47)$. The mean duration of diabetes was 6.72 years $(S D=3.78)$. The mean value of $\mathrm{HbA}_{1 \mathrm{C}}$ was 8.32 ( $\mathrm{SD}=1.53$ ). $27.68 \%$ of the sample was of optimal $\mathrm{HbA}_{1 \mathrm{C}}$ level, while $45.53 \%$ of sub-optimal, and $26.79 \%$ of highrisk $\mathrm{HbA}_{1 \mathrm{C}}$-level. Regarding the type of the applied intensive insulin therapy, we divided the children into two groups. $44.6 \%$ of the sample was treated with Multiple Daily Insulin Injections (MDI), while $55.4 \%$ was treated with insulin pump therapy (Continuous Subcutaneous Insulin Infusion, CSII) (Table 1). Data collection was carried out between September 2016 and December 2017 at the Endocrinology Outpatient Clinic Department of Pediatrics, University of Debrecen, Faculty of Medicine, Debrecen, Hungary.

\section{Measures}

PRISM-D, Drawing version of Pictorial Representation of Illness Self-Measure; Büchi, Sensky, 1999, Havancsák, 2013

The PRISM-D test is the drawing test version of PRISM test [24] developed by Hungarian researchers [25]. Participants have to present their disease on a white A/4 sheet by means of drawing a circle with a red marker. The white sheet symbolises the subject's current life and the yellow pre-printed circle $(7 \mathrm{cms}$ in diameter) in the bottom-right corner represents the Self. First, according to the instruction, participants have to draw their disease on the test sheet without restriction as regards size and position [25]. Then, with optional colour markers, they may display significant factors that can currently be found in their lives. The distance between the centres of the Self-circle and the circle representing the disease (Self-Illness Separation, SIS) [24] implies the extent of the subjective distress caused by the disease. The size of the Illness-circle (IIIness Perception Measure, IPM) [26] refers to the disease perception. This test can provide us with a picture of the complexity of the person's life as well as the factors affecting recovery [27]. During data analysis, we analyzed SIS, IPM, the area and cumulated area, and the number of circles. We also categorised the circles on the basis of their primary meaning. The circles which the children had labelled were examined by three independent reviewers and rated into the following four main content categories: „Significant others”; „Free-time activities, hobbies”; „Futurerelated content, goals"; „School”. The framework created by Hungarian researchers served as the basis of categorization [25]. Since it is a system of categories developed on the adult sample, we have exchanged the category "Work" with category "School”. We analyzed the frequency of content categories and the connection between illness representations and individual resources.

\section{The Cantril Self-Anchoring Striving Scale [28], Life Evaluation Index, [29]}

We used the Life Evaluation Index [29] to measure SWL. The index was developed based on the 11 steps of the Cantril ladder [28]. The Cantril-ladder is a visual analogue scale, which means that the marked step indicates where the responders position themselves between the two endpoints of the scale. Children had to assess their satisfaction with life on an 11-step ladder both now and in five years. Step 10 of the ladder presents the highest, and step 0 presents the lowest level of satisfaction with life in both currently and in the future. The Cronbach-alpha is 0.91 . Gallup [29] created the following three independent groups based on the points achieved on the scale: 
1) „Thriving”: they are characterized by strong and consistent well-being. They view their current life situation as well as the next five years positively. They report significantly fewer health issues, less anxiety, stress, sadness and anger, and more happiness and enjoyment. In their case, the assessment as regards the present scores $\geq 7$ points, and regarding the future $\geq 8$ points.

2) "Struggling”: their well-being is inconsistent. They are moderately satisfied with their-present and future life situations. Compared to the „Thriving” group, they report a higher level of daily stress and anxiety and become ill twice as frequently.

3) „Suffering”: a high-risk group in respect of the development of mental disorders. They are slightly satisfied with their present life and their assessment for the next five years is rather low. They report more somatic symptoms, more severe disease burden, stress, anger, sadness. The assessment of the present and the future is $\leq 4$ points.

Self-rated health, $S R H[30]$

We examined the self-rated health with the following question: „How would you assess your health compared to your peers?”, which children had to assess on a 4-point Likert-scale where 1 = 'poor or bad', 2 = 'fair', 3 = 'good', 4 = 'excellent'. The question proved reliable both with adult and adolescent populations [30].

Child Depression Inventory, CDI, [31, 32, 33]

$\mathrm{CDI}$ is a screening tool of 27 questions applied to measure the level of depression among children of 7 to 18 years of age, with three answer options $(0,1,2)$ per question. Of the answers, " 0 " stands for the absence of symptoms, "1" for mild symptom manifestation, and „2" for clinical level manifestation of symptoms for the previous two weeks. The maximum score is 54 points. In this study, we worked with two cut-off points; we separated subclinical depressive symptoms (13 - 15 points) and clinical depressive symptoms ( $\geq 16$ points). The Cronbach-alpha is 0.92 [33].

\section{Glycosylated haemoglobin}

The haemoglobin $\mathrm{A}_{1 \mathrm{C}}\left(\mathrm{HbA}_{1 \mathrm{C}}\right)$ is an important diabetes-specific indicator. The $\mathrm{HbA}_{1 \mathrm{c}}$ values for blood glucose control were collected from medical reports. The $\mathrm{HbA}_{1 \mathrm{c}}$ test is the most commonly used measure of glycemic control and diagnostic test for T1DM [34]. We determined the severity of illness by the HbA1c indicator, which is recommended by the ISPAD. $\mathrm{HbA}_{1 \mathrm{C}}<7.5 \mathrm{mmol}^{\circ}$ represents optimal metabolic control, between $7.5-9.0 \mathrm{mmol}$ suboptimal, while above $9.0 \mathrm{mmol}$ means high-risk metabolic control.

\section{Statistic analysis}

We used IBM SPSS Statistics v22 for the statistical analysis of the data. The normality of the variables was assessed by Chisquare test and Kolmogorov-Smirnov test. As most of our variables did not display normal distribution, we used nonparametric statistical analysis. Descriptive statistics were used to analyse the variables of children's mental health. We analyzed the associations between dependent and independent variables using Spearman rank correlation test, Kruskal-Wallis test-and Mann Whitney U test.

\section{Results}

\section{Mental health factors of T1DM-children and adolescents}

The mean CDI-score in the sample was $8.53(\mathrm{SD}=5.96)$, in case of boys $7.2(\mathrm{SD}=5.58)$, in case of girls $9.7(\mathrm{SD}=6.09)$. We did not find significant gender difference $(U=958,00 ; p=0.056)$, although the girls achieved a higher mean score. 75.5\% of the T1DMchildren belonged in the risk-free group. We found that $24.5 \%$ of the children showed subclinical depression while $11.76 \%$ of them were possible to characterize with clinical depression. Examining the association between the type of intensive insulin-therapy and depression, we found that $38.64 \%$ of the children treated with MDI showed subclinical depressive symptoms and $15.9 \%$ of them reported clinical depression. Among children receiving CSII therapy, only $17.24 \%$ reported subclinical symptoms, while $3.45 \%$ was characterized with clinical depression. 
In our sample, the SRH mean of the T1DM-children was 2.74 (SD $=0.69) .60 \%$ of the children assessed their health good, $26.36 \%$ fair, $9.09 \%$ excellent, while $4.55 \%$ assessed it poor or bad. The mean SWL of the T1DM-children was $6.98(S D=1.89)$, and the mean of their future direction was higher, $8.13(\mathrm{SD}=1.66)$. We did not find a significant difference between genders in terms of mental health factors and illness-specific variables.

\section{Correlation between mental health variables}

We found significant differences in mental health factors between groups created by the Life Evaluation Index [28]. Those who were classified into the "Thriving” group reported higher satisfaction with life regarding their present and future life condition as well. They achieved significantly lower CDI-scores (SWL-p: $\chi^{2}=21.347 ; p<0.01$; SWL-f: $\chi^{2}=6.977 ; p<0.05$ ) and better SRH (SWL$p: \chi^{2}=14.73 ; p<0.01 ;$ SWL-f: $\left.\chi^{2}=18.949 ; p<0.01\right)$ than the children in the groups "Struggling" and "Suffering".

Examining the connection of the mental health variables, the strongest correlation was found between satisfaction with life and future direction. We found a moderate correlation between SRH and future direction as well as between satisfaction with life and future direction.

\section{Association between T1DM-children and -adolescents' mental health and illness representations}

The most common content category was „Significant others” (54.4\%), followed by „Free-time activities” (20.63\%), then „Futurerelated content, goals" (15.5\%) and finally "School” (6\%). $14.16 \%$ of the children did not draw significant relationships, and $61 \%$ of them did not display any free-time activities, hobbies. $9.73 \%$ of the participants drew neither significant relationships nor any freetime activities, hobbies at the drawing test. Apart from the Illness-circle, $8.85 \%$ of them drew further content in connection with diabetes, and two children displayed only T1DM-related content. Those children, who did not draw significant relationships, reported a significantly higher depression score than those who drew at least one important personal relationship $(U=379.000 ; p=$ 0.01). Besides, they drew significantly fewer circles apart from the Illness-circle $(U=305.000 ; p<0.01)$ furthermore the aggregate area of these circles was significantly smaller $(U=607.500 ; p<0.05)$ (Figure 1, 2). We found a significant positive correlation between the sizes of the circles in the "Significant others" category and the area of the Illness-circle $(r=0.360 ; p<0.01)$, and between the number of the circles apart from the Illness-circle $(r=0.325 ; p<0.01)$ and the aggregate area of theirs $(r=0.744 ; p<$ 0.01). Regarding the other content categories, no remarkable difference was identified concerning the factors of mental health.

The mean SIS was $8.56(S D=4.0)$, and the mean IPM was $16,66(S D=28,41)$. Based on SIS, our sample can be characterized by a considerable degree of suffering from the disease. The lowest value was $0 \mathrm{~cm}$, and the highest one was $23.5 \mathrm{~cm}$.

Examining the connection between depression and the illness representations we found that the number of circles apart from the Illness-circle $(r=-0.220 ; p<0.05)$ and the sizes of the circles belonging in "Significant others" $(r=-0.253 ; p<0.05)$ showed significant correlation with CDI-scores (Figure 1, 2). Besides, there appeared to be a tendentious association $(r=-0.181 ; p=0,069)$ between the number of the circles of "Significant others" and CDI-scores. We did not find a significant difference between illness representations and the other factors of mental health (SRH, SWL-p, SWL-f).

\section{The relation of diabetes-specific variables with mental health variables and illness representations}

Examining the connection between the children's illness representations and the duration of diabetes we found a significant negative correlation between the two variables, which means that the longer ago the diabetes was diagnosed, the lower the SISvalue was $(r=-0.259 ; p<0.01)$ (Figure 3, 4). Moreover, the duration of T1DM showed significant correlation with the SRH-index $(r=$ $0.216 ; p<0.05)$. Regarding the illness representations and the mental health factors, we did not find a significant connection with other diabetes-specific variables such as $\mathrm{HbA}_{1 \mathrm{c}}$, CSII or MDI (Table 2).

\section{Discussion}

Mental health factors of T1DM-children and adolescents In studies applying the Child Depression Inventory, nearly a quarter of the examined T1DM-children: 22.8\% [35], 23\% [36], 25\% [37] showed subclinical or clinical depressive symptoms. Similarly to the international results, this proportion in our research was $24.5 \%$. However, according to De Wit and Snoek's [38] results, the rate of clinical depression symptoms is $17.2 \%$ among T1DM-children. In this study, this proportion was merely $11.76 \% .60 \%$ of T1DM- 
children rated their health good, $26.36 \%$ fair, $9.09 \%$ excellent, while $4.55 \%$ poor or bad. According to the results of Health Behaviour in School-aged Children [39], 28.9\% of the Hungarian children and adolescents assessed their health condition excellent, $51.4 \%$ good, $17 \%$ only fair and $2.8 \%$ poor or bad. Our results are indicating that the self-rated health of T1DM-children is considerably poorer than the results of the Hungarian representative sample used in the HBSC-study. Hence T1DM-children form a high-priority risk group in respect of poorer health condition. The gender difference described in the HBSC-study implies that boys assessed their health better than girls. However, in the current study, there appeared no such difference between genders in the group of T1DMchildren. Previous studies using larger adult samples $[15,16]$ identified as protective factors of $\mathrm{SRH}$, the female gender, the shorter T1DM-duration, the younger age at the onset of disease, as well as the lower HbA1C-level. In the current study, however, we did not find such relations, which is likely explained by the small sample size and the diverse age-groups. Comparing the T1DM-children's satisfaction with life with the Hungarian results of HBSC [39], we can conclude that children living with diabetes are almost as satisfied with life as their healthy peers. We can conclude from our results that children with T1DM are satisfied with their lives to nearly the same extent as the children in the national representative sample. It means that the former ones do not consider T1DM as an inhibiting factor of their life, but as a condition highly possible to control through self-management. Correlation of mental health variables Children who were more satisfied with their present life and future direction fell by Gallup's classification under the group „Thriving”. They are characterized by a particular stable, consistent well-being, and fewer health issues, negative feelings, stress and distress [29]. Our result, according to which the "Thriving" reported significantly better health condition and fewer depressive symptoms, supports Gallup's description. The lower level of self-rated health and a higher number of depressive symptoms ("Struggling” and „Suffering”) match the characteristics of these two groups as well. In many cases they have limited access to medical services and, as opposed to the group "Thriving”, they are characterized by twice as intense disease burden. The members of these two groups appear, therefore to be a high-risk group within the T1DM-population as regards the development of mental problems. For this reason, we consider it utmost important to screen this patient population for mental health issues within medical care. Similarly to previous researches $[40,41]$ examining the relationship between mental health variables, we found that those T1DM-children who reported better health condition, higher satisfaction with life and a more positive future direction were more likely to be characterized with significantly better emotional state. The association between T1DM-children and adolescents' mental health characteristics and their illness representations During the analysis of PRISM-D test, we encountered with various meanings of content. Of the four categories that we established by content analysis, „Significant others” appeared the most frequently. Based on our findings, we can conclude that the connection with family members and friends play an important role in the lives of T1DM-children. Those children who did not present meaningful personal relationships which could serve as resources to them through social support were far more likely to develop depressive symptoms. By using a nonverbal drawing test, we also confirmed the fact that the supportive social atmosphere in the child's life is a highly crucial protective factor against the development of depression. The negative emotional state or mood the children reported manifested itself in the smaller number and size of the circles. T1DM-children with higher depression scores drew, on the one hand, significantly fewer circles (apart from the Illness-circle) and on the other hand the number and the size of the circles in the category "Significant others" were considerably smaller. On the basis of theinformation mentioned above, we can conclude that the fewer resources there are in children's lives, the less protected against the development of depressive mood they are. In accord with the findings of Havancsák et al. [25], we found that the larger the 'Illness' and the 'Significant others' circles were, the larger they drew the circles symbolizing the resources too. One possible explanation for this can be the fact that the disease plays a more significant role in the patients' lives, the more they need social support. The increase in the size of the circles can be explained with the possible mediating effect of distress.

According to the results of previous studies, patients with higher anxiety drew significantly larger organs in projective drawing tests $[42,43]$. The associations between diabetes-specific variables, mental health variables and illness representations Regarding diabetes-specific variables, mental health variables and illness representations we found that those children who were diagnosed earlier, drew the Illness- circle significantly closer to the Self-circle and reported higher levels of self-rated health than their more recently diagnosed counterparts. Our conclusion from this is that the experience of living diabetes as a chronic disease over the years - following the initial emotional shock reaction - can transform from a life-threatening state with compelling limitations into a sort of acceptive coexistence. The distance between the centre of the Self-circle and the centre of Illness-circle refers to the intensity of the subjective suffering [27]. Sándor and Csabai [27] found larger distance between the "Self"-circle and the "IIIness"circle $(M=10.62)$ among cancer patients. They explained this association with the highly intensive suffering from the disease. In the current study we found a somewhat smaller distance between the centres of the two circles $(M=8.56)$ in case of T1DMchildren, however, not even on this basis may we consider their suffering from their illness marginal. 


\section{Conclusion}

The examination of illness representations adds important and new aspects of professional work with T1DM-children. Since the verbality-based and concrete conceptual thinking ability stabilizes after the age of 10, children can express their emotions, desires and fears by nonverbal tools such as drawings far more easily. We were the first to apply the PRISM drawing test to explore the illness representations of children - and among them of a special patients group: children with T1DM - and to examine the connection of these representations with various disease-specific variables and health indicators. With a more complex understanding of T1DM-children's illness representations, their psychotherapic treatment can become more effective, which can positively affect their quality of life and their mental health. This provided the novelty of the research. When we investigate children with T1DM in a multiple way with quantitative and qualitive methods, deeper and more detailed results can be found. Also, applying PRISM-D test as a quantitative method we can see an other side so the real self-esteem and mental representations of the children. This can support us not only in research finfings but also int he individual psychological treadment of the patients. Based on our findings, we recommend the use of PRISM-D among T1DM-population as well as children living with other chronic diseases. The PRISM-D may be a feasible instrument to measure diabetes-related suffering. Furthermore, we can obtain a more complex understanding of children's illness perception, emotional state and available resources, all of which can provide significant help in their individual and group psychotherapy.

As limitations, we may mention that our results cannot be generalized for the population of T1DM children and interpretations are limited due to our non-representative small sample size. It would be undoubtedly beneficial to carry out into a broader cooperation a similar examination with a representative sample as well as a longitudinal study of the illness representations and mental health factors of the children population with diabetes. The repeatability of the test enables the clear monitoring of changes in the children's representations and the improvement of their coping strategies. Additionally, due to the nature of self-reported questionnaires and measures, response biases (i.e. social desirability or recall bias) must be taken into consideration. Although there is no standard to compare our results to - since PRISM-D was originally established for the examination of adult illness representations and had never been used among children -, but, at the same time, this is what makes our study a groundbreaking one.

\section{Abbreviations}

CDI - Child Depression Inventory

CSII - Continuous Subcutaneous Insulin Infusion

$\mathrm{HbA}_{1 \mathrm{C}}$ - Glycohemoglobin

HBSC - Health Behaviour in School-aged Children

HRQoL - Health-Realted Quality of Life

IPM - IIIness Perception Measure

ISPAD - International Society for Pediatric and Adolescent Diabetes

MDI - Multiple Daily Insulin Injections

PRISM-D - Drawing version of Pictorial Representation of Illness Self-Measure

SIS - Self-IIIness Separation

SRH - Self-rated Health

SWL - Satisfaction with Life

SWL-f - Satisfaction with Life-future

Page $7 / 14$ 
SWL-p - Satisfaction with Life-present

T1DM - Type 1 Diabetes Mellitus

\section{Declarations}

Author contributions: All the authors have accepted responsibility for the entire content of this submitted manuscript and approved submission.

Research funding: Declaration or None declared.

Employment or leadership: None declared.

Honorarium: None declared.

Competing interests: The funding organization(s) played no role in the study design; in the collection, analysis, and interpretation of data; in the writing of the report; or in the decision to submit the report for publication.

Our research was approved by the Regional Istitutional Research Ethics Committee, Clinical Center, University of Debrecen (ID: 4528A-2016) following the ethical principles of WMA Declaration of Helsinki. Written informed consent was obtained from all participants.

\section{References}

1. Kovács M, Obrosky DS, Goldston D, Drash A. Major Depressive Disorder in Youths IDDM: A controlled prospective study of course and outcome. Diab Care. 1997; 20: 45-51.

2. Lernmark B, Persson B, Fisher L, Rydelius PA. Symptoms of depression are important to psychological adaptation and metabolic control in children with diabetes mellitus. Diabet Med. 1999; 16: 14-22.

3. Ducat L, Rubenstei A, Philipson LH, Anderson BJ. A review of the mental health issues of diabetes conference. Diab Care. 2015; 38: 333-338.

4. Rewers A, Chase H.P, Mackenzie T, Walravens P, Roback M, Rewers M, et al. Predictors of acute complications in children with type 1 diabetes. JAMA. 2002; 287: 2511-2518.

5. Stewart SM, Rao U, Emslie GJ, Klein D, White PC. Depressive symptoms predict hospitalization for adolescents with type 1 diabetes mellitus. Pediatrics. 2005; 115: 1315-1319.

6. Grey M, Whittemore R, Tamborlane W. Depression in type 1 diabetes in children: natural history and correlates. J Psychosom Res. 2002; 53:907-911.

7. Reynolds KA, Helgeson VS. Children with diabetes compared to peers: depressed? Distressed? A meta-analytic review. Ann Behav Med. 2011; 42: 29-41.

8. Diener E. Subjective well being: The science of happiness, and a proposal for a national index. American Psychologist. 2000; 55: 34-43.

9. Jylha M, Guralnik JM, Ferrucci L, Jokela J, Heikkinen E. Is self-rated health comparable across cultures and genders? J Gerontol B Psychol Sci Soc Sci. 1998; 53(3): 144-152.

10. Kriston P, Pikó B, Kovács E. Self-rated health indicator as an indicator of mental well-being: Behavioral epidemiological analysis of adolescent population. [Az önminősített egészségmutató, mint a pszichikai jóllét indikátora: serdülő populáció körében végzett magatartás-epidemiológiai elemzés.] Orv Hetil. 2012; 153: 1875-1882. [Hungarian]

11. Han B, Phillips C, Ferrucci L, Bandeen-Roche K, Jylha M, Kasper J, Guralnik JM. Change in self-rated health and mortality among community-dwelling disabled older women. Gerontologist. 2005; 45: 216-221.

12. Ishizaki T, Kai I, Imanaka Y. Self-rated health and social role as predictors for 6-year total mortality among a non-disabled older Japanese population. Arch Gerontol Geriatrics. 2006; 42: 91-99. 
13. Hillen T, Davies S, Rudd AG, Kieselbach T, Wolfe CD. Self ratings of health predict functional outcome and recurrence free survival after stroke. J Epidemiol Comm Health. 2003; 57: 960-966.

14. Long MJ, Marshall BS. The relationship between self-assessed health status, mortality, service use, and cost in a managed care setting. Health Care Manage Rev. 1999; 24: 20-27.

15. Huang GH, Palta M, Allen C, LeCaire T, D'Alessio D. Self-rated health among young people with type 1 diabetes in relation to risk factors in a longitudinal study. Am J Epidemiol. 2004; 159(4): 364-72.

16. Undén AL, Elofsson S, Andréasson A, Hillered E, Eriksson I, Brismar K. Gender differences in self-rated health, quality of life, quality of care, and metabolic control in patients with diabetes. Gend Med. 2008; 5(2): 162-80.

17. Shibuya K, Hashimoto H, Yano E. Individual income, income distribution, and self rated health in Japan: cross sectional analysis of nationally representative sample. BMJ. 2002; 5324(7328): 16-9.

18. Garratt AM, Schmidt L, Fitzpatrick R. Patient-assessed health outcome measures for diabetes: a structured review. Diabet Med. 2002; 19(1): 1-11.

19. Idler EL, Benyamini Y. Self-Rated Health and Mortality: A Review of Twenty-Seven Community Studies. J Health Soc Behav. 1997; 38: 21-37.

20. Bond J, Dickinson HO, Matthews F, Jagger C, Brayne C. Self-rated health status as a predictor of death, functional and cognitive impairment: a longitudinal cohort study. Eur J Ageing. 2006; 83(4): 193-206.

21. Viner RM, Ozer EM, Denny S, Marmot M, Resnick M, Fatusi A, et al. Adolescence and the social determinants of health. Lancet. 2012; 379(9826): 1641-1652.

22. Széll K, Kiss E. Investigation of the relationship between disease representation and quality of life in people with stomach. [A betegségreprezentáció és életminőség kapcsolatának vizsgálata sztómával élők körében.] In: Kiss E, Polyák L, eds. Health Rehabilitation Booklets II. The role of personal and social factors in rehabilitation work. [Egészség Rehabilitációs Füzetek II. A személyes és társas tényezők szerepe a rehabilitációs munkában] Budapest: Oriold and Partners Publisher; 2012: [Hungarian]

23. Petrie KJ, Weinman J. Patients' perceptions of their illness: The dynamo of volition in health care. Curr Dir Psychol Sci. 2012; 20(10), 1-6.

24. Büchi S, Sensky T. PRISM: Pictorial Representation of Illness and Self Measure: A brief nonverbal measure of illness impact and therapeutic aid in psychosomatic medicine. Psychosomatics. 1999; 40(4): 314-320.

25. Havancsák R, Pócza-Véger P, Csabai M. The PRISM-D drawing test in the study and treatment of hospital patients. [A PRISM-D rajzteszt kórházi betegek vizsgálatában és kezelésében.] In: Csabai M, Pintér J. N. eds. Psychology in Healing. Phenomenological, art psychological and body-centered approaches. [Pszichológia a gyógyításban. Fenomenológiai, múvészetpszichológiai és testkép-központú megközelítések.]. Budapest: Oriold and Partners Publisher; 2013: 83-107 [Hungarian]

26. Reimus JL, Vingerhoets AJ, Soons PH, Korstanje MJ. Suffering in psoriasis patients: its relation with illness severity and subjective well-being. Int J Dermatol. 2007; 46: 1042-1045.

27. Sándor Z, Csabai M. Using the PRISM-D Drawing Test to Complex Examination of Emotional and Cognitive Representations Related to Cancer Disease. [A PRISM-D rajzteszt alkalmazása a daganatos betegséggel összefüggő érzelmi és kognitív reprezentációk komplex vizsgálatára.] Orv Hetil. 2018; 159(48): 2021-2030. [Hungarian]

28. Cantril H. The pattern of human concern. New Brunswick: Rutgers University Press; 1965.

29. Gallup DS. Worldwide Research Methodology and Codebook. London: Gallup, Inc:, 2016.

30. Pikó B, Barabás K, Boda K. The epidemiology of psychosomatic symptoms and their effect on self-esteem in health among university students. [Pszichoszomatikus tünetek epidemiológiája és hatása az egészségi állapot önértékelésére egyetemi hallgatók körében.] Orv Hetil, 1995; 136(31): 1667-1671. [Hungarian]

31. Kovacs M. The children's depression inventory (CDI). Psychopharmacol Bull. 1985; 21, 995-998.

32. Kovacs M. Children's Depression Inventory (CDI). Toronto, ON: Multi-Health Systems Inc.; 1992.

33. Rózsa S, Vetró Á, V. Komlósi A, Gádoros J, Kő N, Csorba J. Questionnaire measurement of depression in children and adolescents based on clinical and normative sample experience. [Gyermek- és serdülőkori depresszió kérdőíves mérésének lehetősége a klinikai és normatív mintán szerzett tapasztalatok alapján.] Pszichológia. 1999, 19(4): 459-482. [Hungarian] 
34. American Diabetes Association. Tests of glycemia in diabetes. Diab Care. 2003; 26(1): 106-108.

35. Hood KK, Rausch JR, Dolan LM. Depressive symptoms predict change in glycemic control in adolescents with type 1 diabetes: rates, magnitude, and moderators of change. Diab Care. 2011; 12: 718-723.

36. Goad K. Examining the Mental Health Issues Prevalent in Adolescent Type-1 Diabetics: An Evidence-Based Review to Improve Health. J Diabetes Metab. 2015; 6: 9.

37. McGrady ME, Hood KK. Depressive symptoms in adolescents with type 1 diabetes: associations with longitudinal outcomes. Diabetes Res Clin Pract. 2010; 88(3): 35-7.

38. de Wit M, Snoek FJ. Depressive symptoms and unmet psychological needs of Dutch youth with type 1 diabetes: results of a web-survey. Pediatr Diabetes. 2011; 12: 172-176.

39. Németh Á, Költő A. Health Behaviour in School-aged Children (HBSC): A WHO-collaborative Cross-National Study National Report. Budapest, Hungary: NEFl; 2014.

40. Pikó B. Self-perceived health among adolescents: the role of gender and psychosocial factors. Eur J Pediatr. 2007; 166(7): 701708.

41. Swami V, Chamorro-Premuzic T, Sinniah D, Maniam T, Kannan K, Stanistreet D, et al. General health mediates the relationship between loneliness, life satisfaction and depression. Soc Psychiatry Psychiatr Epidemiol. 2007; 42: 161-166.

42. Broadbent E, Petrie KJ, Ellis CJ, Ying J, Gamble G. A picture of health - myocardial infarction patients' drawings of their hearts and subsequent disability: A longitudinal study. J Psychosom Res. 2004; 57: 583-587.

43. Látos M, Barabás K, Lázár G, Szederkényi E, Szenohradszky P, Marofka F. Mental representations of the new organ and posttransplant patients' anxiety as related to kidney function. Transplant Proc. 2012; 44(7): 2143-2146.

\section{Tables}

Table 1: Anamnestic, demographic and diabetes-specific characteristics of the sample 


\begin{tabular}{|c|c|c|}
\hline Anamnestic variables & Total $(\mathrm{N}=115)$ & P-value \\
\hline Male N; (\%) & $55(47.83)$ & $p=0,456$ \\
\hline Age M; (SD) & $14.13(2.47)$ & - \\
\hline Has a sibling $N(\%)$ & $93 ;(80.86)$ & $p<0.001$ \\
\hline \multicolumn{3}{|l|}{ Demographic variables } \\
\hline \multicolumn{3}{|l|}{ Maternal education N; (\%) } \\
\hline Elementary & $12 ;(10.43)$ & \multirow[t]{3}{*}{$p=0,433$} \\
\hline Secondary & $36 ;(31.30)$ & \\
\hline Higher education & $19(16.52)$ & \\
\hline $\mathrm{N} / \mathrm{A}$ & $48 ;(41.73)$ & - \\
\hline \multicolumn{3}{|l|}{ Paternal education N; (\%) } \\
\hline Elementary & $11 ;(9.57)$ & \multirow[t]{3}{*}{$p=0,435$} \\
\hline Secondary & $32 ;(27.82)$ & \\
\hline Higher education & $20 ;(17.39)$ & \\
\hline N/A & $52 ;(45.21)$ & - \\
\hline \multicolumn{3}{|c|}{ Self-rated socialeconomic status N; (\%) } \\
\hline Below average & $6 ;(5.21)$ & \multirow[t]{3}{*}{$p=0,444$} \\
\hline Average & $73 ;(63.47)$ & \\
\hline Above average & $12 ;(10.43)$ & \\
\hline $\mathrm{N} / \mathrm{A}$ & $24 ;(20.86)$ & - \\
\hline \multicolumn{3}{|l|}{ Diabetes-specific variables } \\
\hline Duration T1DM M; (SD) & $6.72 ;(3.78)$ & - \\
\hline Age at T1DM-onset M; (SD) & & - \\
\hline $\mathrm{HBA}_{1} \mathrm{C} \mathrm{M} ;(\mathrm{SD})$ & $8.32(1.53)$ & - \\
\hline Optimal N; (\%) & $32 ;(27.68)$ & \multirow[t]{3}{*}{$p=0,450$} \\
\hline Suboptimal N; (\%) & $52 ;(45.53)$ & \\
\hline High-risk N; (\%) & $31 ;(26.79)$ & \\
\hline \multicolumn{3}{|c|}{ Type of intensive insulin-therapy N; (\%) } \\
\hline MDI & $51 ;(44.6)$ & \multirow[t]{2}{*}{$p=0,456$} \\
\hline CSII & $64 ;(55.4)$ & \\
\hline
\end{tabular}

Table 2: Correlations between mental health variables, diabetes-specific variables and the PRISM-D ( $r$ ) 


\begin{tabular}{|c|c|c|c|c|c|c|c|c|c|c|}
\hline & \multicolumn{4}{|c|}{ Mental health variables } & \multirow{2}{*}{$\begin{array}{l}\text { T1DM } \\
\text { T1DM } \\
\text { duration }\end{array}$} & \multicolumn{5}{|c|}{ Illness representations (PRISM-D) } \\
\hline & Depression(CDI) & $\begin{array}{l}\text { Self- } \\
\text { rated } \\
\text { health } \\
\text { (SRH) }\end{array}$ & $\begin{array}{l}\text { Satisfac- } \\
\text { tion with } \\
\text { life } \\
\text { (SWL-p) }\end{array}$ & $\begin{array}{l}\text { Future } \\
\text { direction } \\
\text { (SWL-f) }\end{array}$ & & IPM & SIS & $\begin{array}{l}\text { Circles } \\
\text { pc }\end{array}$ & $\begin{array}{l}\text { Circles } \\
\mathrm{T}^{\mathrm{a}}\end{array}$ & $\begin{array}{l}\text { Signifi- } \\
\text { cant } \\
\text { others } \\
\mathrm{T}^{\mathrm{a}}\end{array}$ \\
\hline $\begin{array}{l}\text { Depression } \\
\text { (CDI) }\end{array}$ & 1.00 & $-\overline{0.28 * \star}$ & $-0.44^{\star *}$ & $-0.29 *$ & -0.90 & 0.97 & -0.01 & $-0.22^{\star *}$ & -0.13 & $-0.25^{\star}$ \\
\hline $\begin{array}{l}\text { Self-rated } \\
\text { health } \\
\text { (SRH) }\end{array}$ & & 1.00 & $0.37 * \star$ & $0.44 * *$ & $0.21 *$ & 0.06 & -0.08 & 0.08 & -0.04 & -0.01 \\
\hline $\begin{array}{l}\text { Satisfaction } \\
\text { with life } \\
\text { (SWL-p) }\end{array}$ & & & 1.00 & $0.60 * *$ & 0.10 & -0.01 & -0.07 & 0.05 & -0.01 & -0.01 \\
\hline $\begin{array}{l}\text { Future } \\
\text { direction } \\
\text { (SWL-f) }\end{array}$ & & & & 1.00 & 0.13 & -0.12 & -0.14 & 0.03 & -0.10 & -0.03 \\
\hline $\begin{array}{l}\text { T1DM } \\
\text { duration }\end{array}$ & & & & & 1.00 & -0.02 & $-0.25^{\star \star}$ & 0.01 & -0.16 & -0.01 \\
\hline IPM & & & & & & 1.00 & 0.09 & -0.02 & $0.53^{\star *}$ & $0.36^{* *}$ \\
\hline SIS & & & & & & & 1.00 & -0.01 & 0,11 & 0.16 \\
\hline Circles pc & & & & & & & & 1.00 & $0.42^{\star \star}$ & $0.32 * *$ \\
\hline Circles $\mathrm{T}^{\mathrm{a}}$ & & & & & & & & & 1.00 & $0.74^{\star \star}$ \\
\hline $\begin{array}{l}\text { Significant } \\
\text { others } T^{a}\end{array}$ & & & & & & & & & & 1.00 \\
\hline
\end{tabular}

Spearman rank correlation $(r),{ }^{*} p<0.05 ;{ }^{* \star} p<0.01$

$\mathrm{a}=$ Aggregate area

\section{Figures}

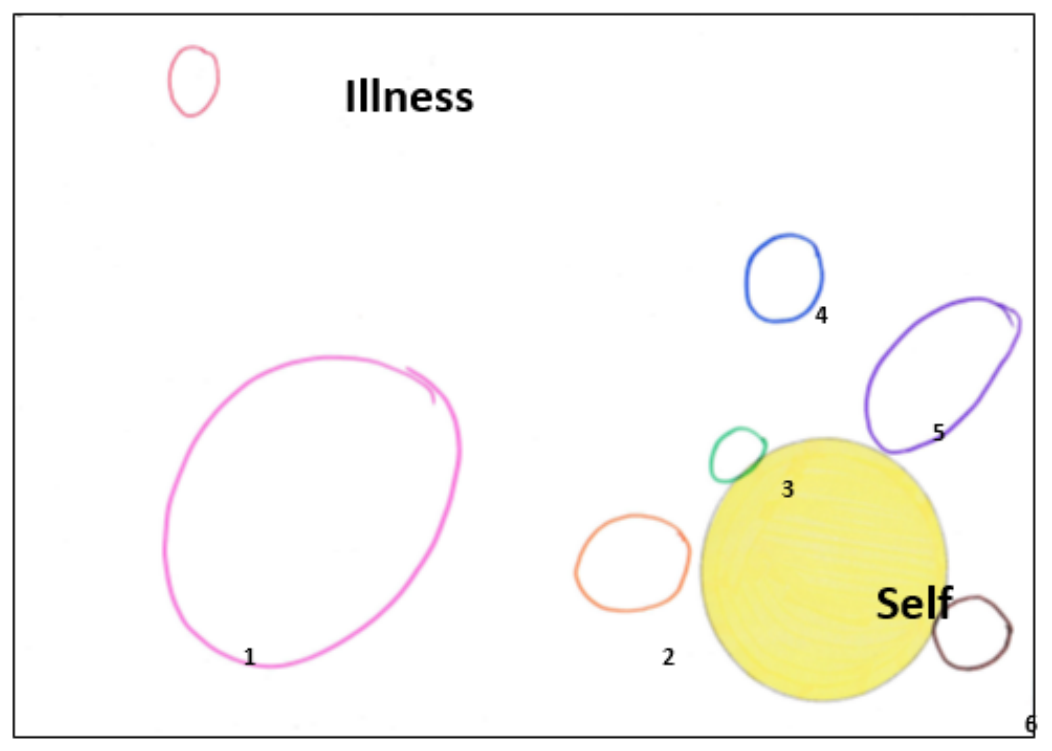

Figure 1 
This is the PRISM-D test of a 9-year-old boy with T1DM. He illustrated 6 life areas that were important to him 3 of which could be classified into the content category „Significant others” („Mom”, Jocóka” - sibling, „Cousins”). He did not report any depressive symptoms $(\mathrm{CDI}=0) .1$ =Environmental science class; $2=$ =ocóka; $3=$ Mom; 4=Cousins; $5=$ Maths competition; $6=$ Maths study group

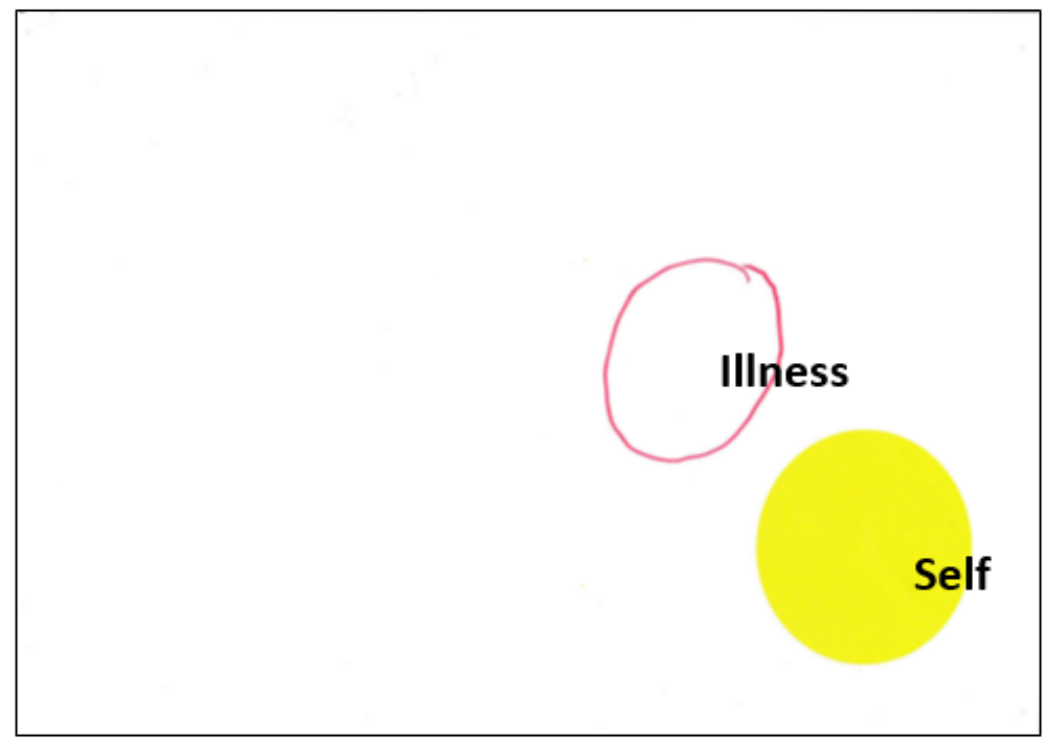

\section{Figure 2}

This is the PRISM-D test of a 12-year-old girl with T1DM. She did not illustrate any significant life areas other than the circle of "Illness". Based on her CDI-score (CDI=25) she can be characterized as having clinical depressive symptoms.

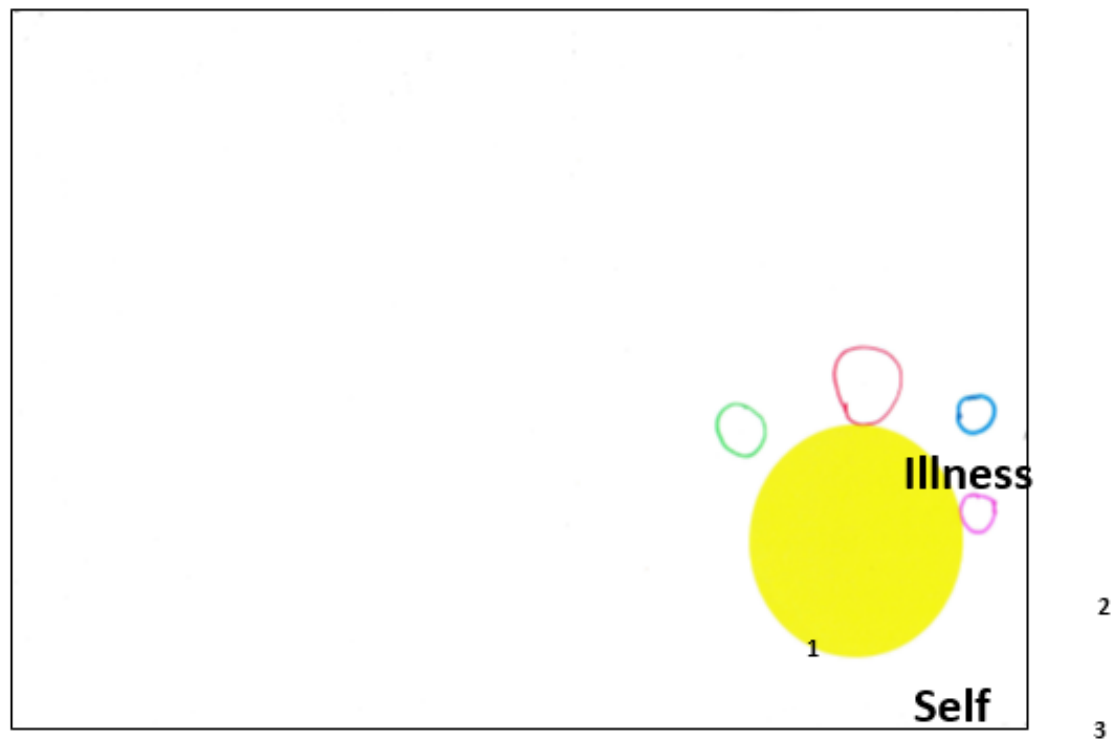

\section{Figure 3}

This is the PRISM-D test of a 15-year-old girl with T1DM. The spatial position of the circle symbolising the illness: small Self-Illness distance (SIS=4.5 cm), the „Illness"-circle and the „Self”-circle are touching. T1DM was diagnosed 11 years ago. 1=Family; 2=Friends; $3=$ Art 


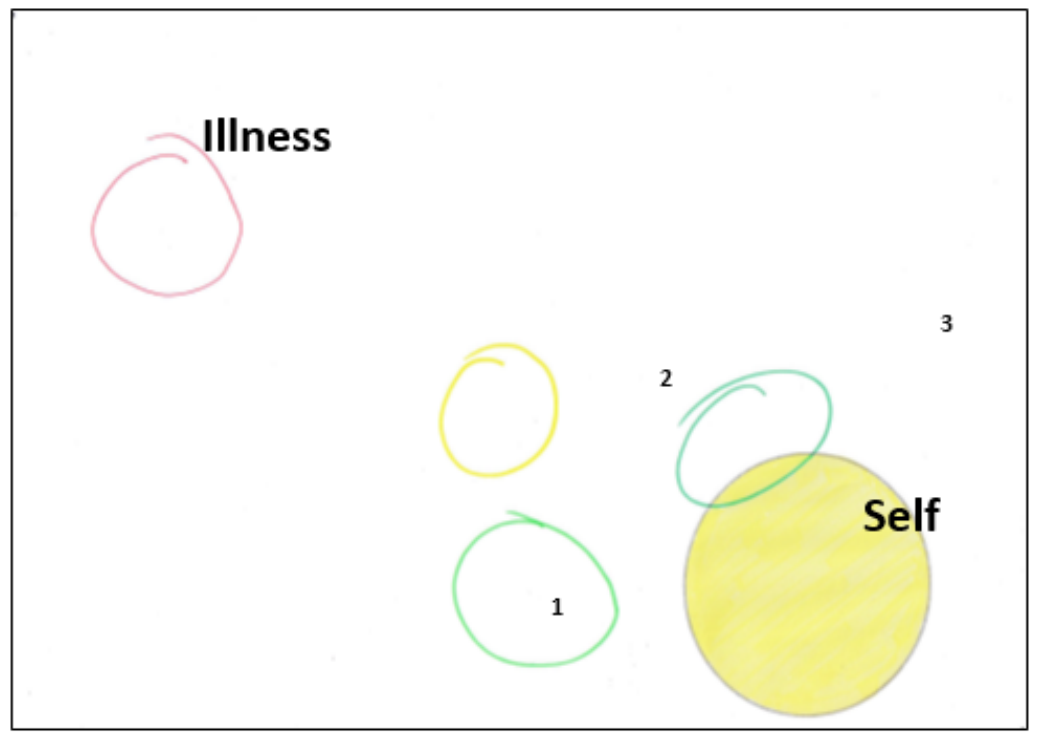

Figure 4

This is the PRISM-D test of a 12-year-old boy with diabetes. The spatial position of the circle symbolising the illness: large SelfIllness distance $(\mathrm{SIS}=21 \mathrm{~cm})$. T1DM was diagnosed 6 years ago. 1=Friends; 2=Sport; 3=Family 